\author{
A.Zh. Anesova, E. Zhumataeva \\ S. Toraighyrov Pavlodar State University, Kazakhstan \\ (E-mail: anesova_albina@mail.ru)
}

\title{
The role of Zh. Aimautov's basic principles in teaching psychology to future specialists
}

\begin{abstract}
This article considers Aimauytov's basic principles in teaching psychology for future specialists. Big role in this process belongs to future specialists who immediately realize these tasks in practice. Training future specialists in higher educational institutions of the necessity of determining the theoretical bases of teaching about the psychology and pedagogical heritage of Zh. Aimauytov also poses challenges before us. Aimauytov studies psychology as a starting point source, from the extreme to the state of his life. Aimauytov argues that the memory of the revival of the human soul has two different characters: «spinal memory» and "philosophical memory». When designing a specific learning outcome, the teacher predicts the unknown (stochastic value) of each student's inner world. Here the effect is not amenable to design, and intelligence and freedom are the heart of education. The success of a teacher lies in the ability to analyze experience, find and put into practice the best achievements in learning. Zh. Aymauytov left us an invaluable spiritual heritage, adapting it to national education. Some of his tips, which are extremely important in the training of teachers, are aimed at providing individual training — the main task of education.
\end{abstract}

Keywords: basic national ideas, psychology, future specialists, spinal memory, philosophical memory, the person's soul, competence, growing ability, intelligence.

\section{Introduction}

In the process of preparing future specialists for higher education, the need to identify the theoretical foundations of teaching Zh. Aimautov's psychological and pedagogical heritage is new. In Aimauytov's book called «Psychology» it is said that this doctrine is studying the person's soul [1]. Personality traits attach importance to its development depending on the scale of the educational level. Thus, Aimauytov argues that the memory of the revival of the human soul has two different characters: spinal memory and philosophical memory. Spinal memory is an attempt to remember the amount of knowledge that must be mastered in a certain way.

Philosophical memory serves as a conscious development of students' philosophical considerations patterns, principles of knowledge necessary for the development. In particular, the world outlook of the person is awakened. In case of development of two characteristics of the given memory at the same time sensory mechanisms of sensitivity of deafness of the person open, opportunities for development of ability to think, comprehend are created. Thus, Aimauytov $[1 ; 24,25]$ sees the following connection between a human and their soul:

- From birth, a person can obtain certain art, service, and ability;

- Whoever works in his own way will get a benefit for his own and the community;

- It will be bread and a blessing for a person to act and to serve in his place;

Aimauytov [1;45] summarized the following conclusions.

1) A person who has not been able to find his way to his own place and difficulty in life;

2) Because many people are on the same path, with a wave of excitement, the most important gold in life is waste;

3) From the time of departure, a person is slaughtered and abandoned by his life, and is burdened with, frustrated and cared for, all the symbols in the surrounding area become black, look at everything with frustration, fate, self-esteem and unhappiness.

Hence, from the three conclusions, it is observed that the three most important of these important plants are the disease. The benefit of the science education is the productive work of each person. When we look at the present concept with the worldview, the paradigm dimension, we cannot bring any benefits to the society, as individuals do not tire of personality and vigor. When a person is overwhelmed with anxiety, it can be a disaster. This means that knowledge of cognitive activities is of paramount importance to individuals before the society. If a natural person finds his way correctly, he has the right to do something useful for the public and society. Specifically, each person is in harmony with his nature, the abundance of abilities, and his / her 
intelligence, and there is no consensus between the social and the individual. A person who has not found his way is unstable in his / her actions; rapid overheat, fast sweating; sagacity and frustration of knowledge; coloration; elasticity; career; consultation; profitability; failure to judge himself; absence of main purpose and ideals; and that he does not become a society or a social worker with sick behaviors, such as not having a good attitude. Hundreds of thousands of professionals are required to know the art of the Kazakh people and other nations and nationalities, as well as how much they need to have a culture of happiness and culture», Aimauytov proclaimed $[1 ; 56,57]$. The integrative type of knowledge is formed in the educational process of the primary school, combining direct experience, system thinking, non-traditional approach to the problem, intuition, analogy, associative thinking, since when integrating knowledge, differences and characteristic features of objects and phenomena are not leveled, on the contrary, integration knowledge while maintaining their essential features $[10 ; 135]$.

\section{Main part}

In the nucleus, the ability to have a family education, a school, and a social science is an indication of the need for self-identification in order to understand the inherent ability. Aimauytov notes the factors that hinder himself:

1. Absence of experience;

2. Their mood is volatile and tense;

3. It is located at a quadruple line;

4. Darkness of the perpendicular pathway [1;78].

It is up to the literacy of the family to be able to account for what kind of profession is flexible in order to be able to find the right person to self-knowledge. While he is in a position of unworthy service, the personality of the individual is dissatisfied, and his behavior is uncertain in the outward appearance, and the severity of service is lost. Because of his discretion, he is not indifferent to the position of the individual. This leads to the pessimistic tendency of the individual to be ashamed of his individuality. To prove this point, let's pay close attention to his words: «A ruthless person is rarely exposed to life. Many will not be able to follow the dreams of all kinds of art forever. Such people do not have any passion or interest in certain art. The secret voice inside is to call for assistance on earth, to go straight to the voice of that voice» $[1 ; 81,83]$.

Zhusupbek Aimauytov was able to convey psychological doctrine on the basis of scientific basis of religion, able to convey the essence of physical, spiritual, and spiritual connections, defining its theoretical significance. He also studied the theoretical aspect of psychology as well as the practical nature. The first representative of experimental psychology was the English philosopher Lott of the 17th century. The second place was taken by a Scottish scientist of the eighteenth century, Yum. Both Lock and Hummel did not recognize the existence of a living psychology, and both of the researchers felt that what I was thinking was not able to find a single thing as «I» when I looked around and understood. The motto of warmth, light, love, hate, matrimony, sorrow, and other feelings of this kind of result has been perceived in the context of the rapidly moving phenomena. As a developer of these conclusions, Aimauytov considered Kant. The main point in Kant's research is that «all the evidence of psychology, which is not matter, but permissible substance, is false». Aimauytov is referred to the Latex of the 19th century German genius as a category of non-living psychology. Although Aimauytov welcomed experienced psychologists, he paid great attention to the fact that Aristotle had a mind-boggling mind-boggling soul. Thus, Aristotle's [2] will also be partly separated. It is presented in the following composition:

- growing ability;

- ability to feel;

- the ability to think.

If we take a picture, we notice that the following model exits:

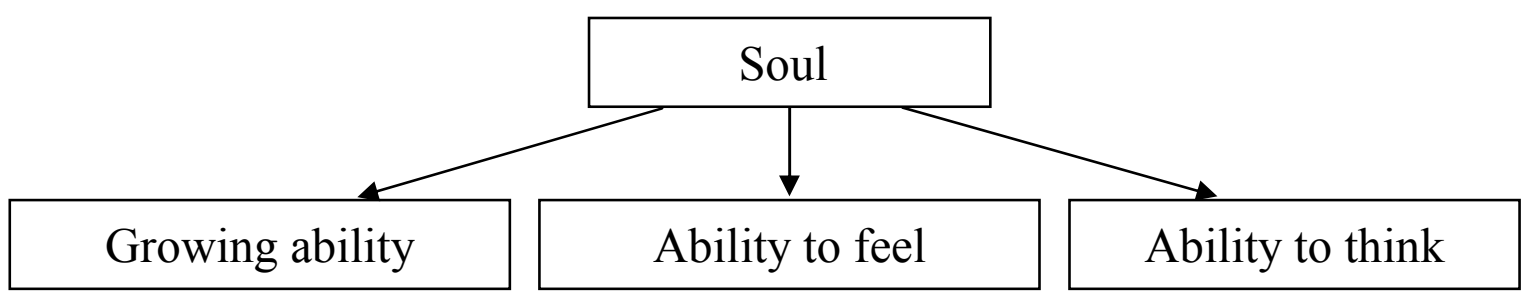

Figure 1. Model of Aristotle's Power 
Figure 1 Aristotle's soul model [2;96]. Likewise, Aristotle's emphasis on cleverness is at stake. It provides it in the following classification: active mind, intelligent mind.

Aristotle [2;98] has considered the mentality model as one system:

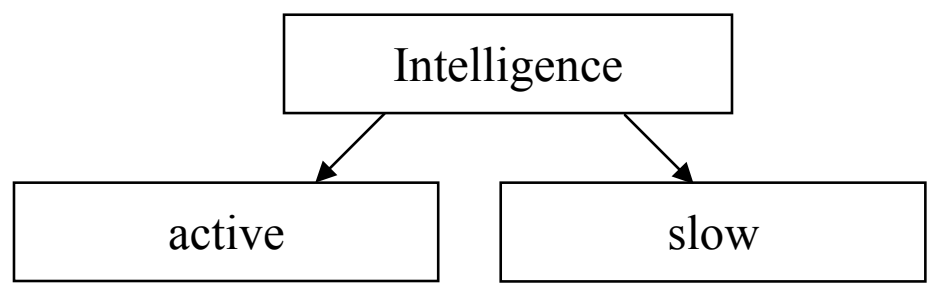

Figure 2. Aristotle's mind-set

It is known in the Republic of Kazakhstan. They are convinced that there are two different approaches. There is no controversy. But some of the above-mentioned comments seem to be too flashy. Psychoanalysts, based on recent seduction, think that losing all the words in old psychology, with the loss of the word «soul». Although they say we lose, they themselves take some words. For example, the characteristics of mind, feeling, courage, memory, gentleness, enthusiasm, imagination, consciousness, and senses are not really pure. It does not have to be the case, Aimauytov says. But they have a lot of emotions, emotions, insights, thought, attention, care, emotions and consciousness. In this case, it can be said that the characteristics of a human being cannot be deduced from known language languages. This word is non-existent, and, as a matter of fact, it is necessary to use other words as well. James, a plethora of psychiatric experts, has come up with words such as intelligence, thought, fortune, consciousness, memory, imagination, emotions, and tactics. James also says that such things are not in good condition [7]. That is why we are convinced that the findings are in harmony with the previous researchers, and that we have been able to identify the various characteristics of human beings with old and new names.

Zhusupbek Aimauytov considers the science of human life as psychology [2]. It is not difficult to find out that such a formula, which was born in the 20th century of the 20th century, in human beings, is that all living things are dying; it is not difficult for Aimauytov to follow Marxist ideology and to adhere to idealistic assumptions. The following extracts prove: «Where does the body depart from the body? Older people realize that soul does not die and lives on its own. The soul of a deceased person flies to heaven. In the blue world, people will have a place to live. It is the soul that comes from the body and the body. Sometimes a soul survives on the part of the off spring and sometimes on the beasts. (It seems that the deceased's person is dependent on faith and faith, rather than by religion). Such fictional tales are like the soul; suggests that there are varieties in each society [3].

It has long been known to us that later generations have always based their work on the scientific findings of scholars. One of these is the fact that Zhusupbek Aimauytov used Abai Kunanbayev's psychological attitudes in his works to clarify his thoughts. So, Abai Kunanbayev: «My mind and soul» — «I am» «The flesh is mine», «I» and «my» are two [4]. When I die from the beginning, the fate of soul dies, and death dies.

The priorities of Aimauytov's conclusion are intuition by the inner voice of the person himself - inappropriate. True, though, he may have to contend with the inner voice of his personality, although he is in the ministry and exaggerating. However, because of the fact that it did not ignore its congenial ability in the choice of profession, now it is too late to correct it. So Aimayutov names such individuals as «tragic» [32; 95]. One of the only possibilities for the self-knowledge of a person is to understand that the brain and the hand are predominant. In the context of public viewpoint, one of those who find out that the person is incapable of doing something is incompatible. Aimauytov is opposed to this opinion. He actually says that the one who started and started moving from one job to another was not a complete person $[32 ; 103]$. It is understood that the criterion of self-ignorance is full of human immaturity, and that it is a sign of labor. Another sign of incompleteness is that in whatever environment they are in, they are able to adapt to the environment. Lack of conclusions. But it is difficult to say that these people are totally inadequate, prone, or lacking in ability. Unfortunately, these are the righteous servants, who at the same time are unable to come to the correct path due to their inherent ability. It is not difficult to observe how each individual's life cycle can grow at different times, as we examine the life course of each individual. It is worthwhile to note that in this case it cannot be said that change in the hierarchical progression from the ramparts in the 
service, due to its inherent ability to make conclusions from the service. In some cases, the individual is always in the process of remembering his or her identity as an act of self-awareness, and may at times be able to perceive congenital energies and capacities. When we read a great deal of scientific works published in Russian, we go through some of the terms and go for the sciences they have invented. One of them is the concept of stochasticity. This means the theory of evolution [32;109-114]. As you can see, Aimauytov proved his wise use of the theory of «chance theory» at the beginning of the 20th century, in his work to develop the path of choice of future generations. In the process of self-identification, Aimauytov pointed out that experimentation will end with the example of those who have worked productively throughout their lifetime $[32 ; 120]$. It is important to note that such practice is a reference to a person's self-knowledge. Thus, Aimauytov points to the legitimacy of the concept of complete human conception with the concept of perfection. In order to attain perfection, large-scale people have a great hope for future goodness, strong faith in their power. Aimauytov's conclusion concludes: "Anyone who searches for something and then finds it to the end, if he has the motivation, talent, will eventually achieve his goal». The «power» and «intention» coincide with one another, and the one that does not have it, goes to waste [32; 236, 237].

In short, each individual must be aware that there is only a small capacity to achieve maturity. Because the inner intent, the position, cannot be used to disperse the energy sources of the individual, that is, the absence of work. These findings show that the labor process does not have any personal qualities. Therefore, before the labor process, it is assumed that the individual will be able to achieve its productivity. In the process of self-identification of the individual, we must first be convinced that if one needs the exterior of the contract immediately to fulfill the requirement, we must be convinced that it is the second property of the bone. In this case, it is important to consider the situation favorable for the individual to be recognized for his or her identity. Aimauytov's personality is presented in two ways. He called the memory and the accumulation of thoughts as «the Ark of Thought» and defined two different ways. The first is a cache memory, and the second is philosophical memory. If the junk memory is overwhelmingly philosophical, there is instability in the ministry. And while the two are developed in a continuous growth, it makes a consistent conclusion that the individual has the ability to attain perfection $[32 ; 241]$. This kind of memory is an individual's ability to memorize a certain form of education and to retain it in its axis [32; 256]. Abay Kunanbayev, a single person from the outside, told him to sing the poem «Do not be proud of science». Well, if the legitimacy of this poem is legal, the author's position, the character of the lyrical character, the sleep, the literary method, etc. if it could reasonably prove that it was philosophical memory. The attempt to test congenital abilities in a person is first revealed as a trap and then philosophical memory. But if one does not develop with the same prosperity law, then a person cannot go on the right path to his or her natural abilities. Thus, the theory of chance suggests that in the process of the acquisition of certain knowledge and sciences, it is the individual's ability to perceive them and go into action. In order to prove such a conclusion, Aimauytov presents one of the most important ideas: «It is necessary to speak only to the person who is the leader, the speaker, who is behind the statement that» Kazakh is a prominent leader, speaker orchestra». If you do not have a good night life, you cannot be a speaker even if you speak until morning» $[4 ; 125]$.

\section{Results}

The physical condition of the individual today is dominated by the choice of service. The number of students who could not get their way out of their total number was $40 \%, 35 \%$ of students who could not get on their own because of their own reasons, $25 \%$ who could not read for external and internal reasons. It has been observed that being able to find the right person to suit his or her own abilities is a guarantee of happiness. Self-knowledge, self-worth makes it possible for the soul to benefit from knowledge and science. In other words, the wise man will be able to test himself in the best sense of justice by reasoning individuals. To prove this point, Aimauytov's conclusion is: «The opinions of others, if they turn into blindness, will distort its true picture and distort it. People say that I'm smart, and I'm really upset that I'm smart. Who knows? In fact, I'm a fool. Often the opinions of others are «foolish» or «boastful», «deceitful» or «slaves». «If you guard your mouth, you will not live on your own, you will be my guardian», says Abai [4; 290].

From this point of view, it is impossible to have self-knowledge of the inherent ability to develop. The driving force behind this is the opinion of others. How can I get to know myself when Aimauytov is in the opinion of others? - I need to put an end to the question of how to get rid of the opinions and criticism of others who are imprudent and imprudent. When faced with such a situation, a person must be self-centered and personalize. Ultimately, staying alone should be considered conditional. It is up to you to be alone as a result of learning how to avoid being overconfident about yourself and improving your training. That is to 
say, self-discipline is carried out properly in a multitude of individuals, when it comes to criticizing and criticizing the overwhelmingly self-criticized criticisms. The person that has embraced in his own self-pervading self-exaltation is the first step in bringing back his «me». As a result, self-esteem is the key and he is motivated to forget about the unfair view of others and to exclude them from his consciousness, and eventually finds a firm belief in himself. Others do not have the opinion of someone else, so the personality of a person is increasing from day to day. True $\langle\mathrm{I} \gg$ »- the state of our consciousness, the indicator of our congenital abilities [6]. No matter how much a person sees him, it does not produce enough results. The main reason is more than just realizing the truth. Where there is a sense of emotion, the reality is deviated. If a person who is living with himself wants to produce the truth, he should not look at emotionally or emotionally when he is out of sight. An individual should be able to direct his / her consciousness to the condition of his / her own health, studying in the process of studying the exact dimensions and aspirations. Like other people, when they are angry or do not know what to say or do, other types of emotions do not make a realistic price. If a person achieves the ability to control his anger, then many human, moral qualities will definitely prosper [7]. Aimauytov says one person should be blown up for self-identification. It recommends that two people be replaced. Recognition of self-identification is provided in a diary. Every day, when a person can mirror his own shape, Aimauytov tells us that yesterday, «I» and «My» are different, they are different.

Ultimately, in order to develop congenital abilities, one must first be self-aware and tested with his rational thinking, without any sensitivity, to conceal his own body and philosophy with scientific and educational objects related to a specific subject or profession. Human beings have the unique ability to evaluate the state of their physical or physical power (Abay's) and the power of the soul, as an indispensable tool for finding a congenial property more quickly. We call the self -renewal or breakthrough of the human being around him. The difference of this slope shows the individual qualities of each person. In human self-knowledge, inspiration plays a key role. Aimauytov's statement that the individual should be guided by science in order to understand himself and others is still actual. Self-reliance is the driving force behind finding the right place in the future. We conclude that its optimal prosperity can only be met in a fair fashion [8].

\section{Conclusion}

Aimauytov is proud of the doctrine of religion. Especially the belief in soul is linked to religion. Anxious about the religious psychology of the Soviet era, a frightened researcher on the 20th century's European culture tells about the culture of the ancient Greek Judaism as an example of a mature culture. By the way, Aimauytov does not disclose psychology's teachings separately from religion, and today, in the context of the integration principle, it does not explicitly state that psychology is inextricably linked with physiology, philosophy, linguistics and religion. It is known that Pythagoras did not have a clear understanding of the geometry theorists of the theorem about the doctrine of «peacock» [9]. It is not surprising that Pythagoras, who considers this person's face into three, is bound by the notion that «the soul + soul will be spirit» is equal to the hypotenuse of the two folds. If he had been trained in the first doctrine, anybody would have to ask themselves what he was asking himself, «What is a personality?», «What's a soul?», «What is spirit?» [10]. Unfortunately, because of the materialistic spirit of religion-related psychology, it is definitely not a matter for the person, the person to acquire the knowledge and scientific notion that it will eventually become familiar with the school program. We conclude, then, that we, teachers, students and pupils are well aware of education [11]. Taking into account age characteristics of perception of information, ability to work in the information environment at a young age, understanding the role of information and communication technologies in education and public life becomes an important component of the competence of a modern teacher [12].

Aimauytov studies psychology as a starting point source, from the extreme to the state of his life. For one of the main reasons we come up with this conclusion, it is clear from the following extract: «At first, there were wild, cattle, horns, strong beasts, animals that looked scary. Therefore, the human father was considered a God, worshiping animals as a God [5]. He was strong in the daytime, and the spell of his ancestors, who had killed the enemy, was stronger than he was when he died. (Kazakh has not lost it yet.)

As we can see, the conclusions proposed by Aimauytov on scientific and practical psychology and pedagogy make sure that there is a practical basis for the professional training of present and future specialists. 


\title{
References
}

1 Аймауытов Ж. Психология / Ж. Аймауытов. - Алматы: Рауан, 1995. - 312 б.

2 Аристотель. Шығармалар жинағы /Аристотель. - М.: Мысль, 1983. - Т.1. - 112 б.

3 Шорманов Ж.Р. Жаңа технология — заман талабы / Ж.Р. Шорманов. - Алматы: Білім, 2004. — 160 б.

4 Құнанбаев А. Өлеңдер жинағы / А. Құнанбаев. - Павлодар: ҒӨФ «ЭКО», 2003. — 2526.

5 Тұрысбек Р. Жүсіпбек Аймауытұлының әсемдік әлемі / Р. Тұрысбек. - Алматы: Қазақ университеті, 2003. - 320 б.

6 Жұмабаев М. Педагогика / М. Жұмабаев. - Алматы, 1999. - 112 б.

7 Мазилов В.А. Актуальные методологические проблемы современной психологии / В.А. Мазилов // Ярославский педагогический вестн. - Т. 2, № 2 (психолого-педагогические науки). - 2013. - С. 149-155.

8 Жұматаева Е. Жоғары мектеп дидактикасы / Е. Жұматаева. - Павлодар: ҒӨФ «ЭКО», 2006. — 316 б.

9 Kudarova N. The role of character in the development of leadership skills of students / N. Kudarova, G. Tulekova, S. Aubakirova, A. Anesova // Journal «Opsion». — 2019. — № 88. - 622-643 p.

10 Berezov, N.A. Fundamentals of psychology and pedagogy: textbook / N.A. Berezov. V.T. Chepikov, M.I. Chekhovsky. — Minsk: New Knowledge LLC, 2004. - 336 p.

11 Attewell P. Competing explanations of undergraduate noncompletion / P. Attewell, S. Heil, L. Reisel // American Educational Research Journal. — 2011. — № 48. — C. 536-559.

12 Rybalko O.A. Studying numbering of numbers in elementary school with the use of interactive electronic posters / O.A. Rybalko // Bulletin of the Karaganda University. «Pedagogy» series. — 2019. — № 4 (96). — 113.

\section{А.Ж. Анесова, Е. Жуматаева \\ Болашақ мамандарға психологияны оқытуда Ж. Аймауытовтың негізгі ұстанымдарының рөлі}

\begin{abstract}
Мақалада болашақ мамандарға психологияны оқытудағы Ж. Аймауытовтың негізгі ұстанымдары қарастырылған. Бұл үрдісте болашақ мамандарға үлкен міндет жүктеледі, олар осы міндеттерді ic жүзінде жүзеге асырады. Жоғары оку орнында болашақ мамандарды даярлау үдерісінде Ж. Аймауытовтың психологиялық-педагогикалық мұраларын оқытудың теориялық негізін айқындау міндеттер қойып отыр. Ж. Аймауытов психологияны экстремалды жағдайдан бастап тіршілік көзі ретінде зерттейді. Ол адамның жанын өркендетуінің жадын екі түрлі сипатта деп тұжырымдайды: «жұлма жад», «философиялық жад». Окудың нақты нәтижесін жобалау кезінде мұғалім әр оқушының ішкі әлемінің белгісіздігі (стохастикалық мәні) туралы болжайды. Мұнда әсерді жобалау мүмкін емес, ал ақыл мен еркіндік білімнің жүрегі болып табылады. Болашақ маманның жетістігі - тәжірибені талдай білу, оқудың ең жақсы жетістіктерін табу және іс жүзінде қолдану. Ж. Аймауытов бізге ұлттық тәрбиеге бейімдеп, баға жетпес рухани мұра қалдырды. Мамандарды даярлауда оның кейбір кеңестері өте маңызды, білім берудің басты міндеті - жеке дайындықты қамтамасыз етуге бағытталған.
\end{abstract}

Кілт сөздер: негізгі ұлттық ойлар, психология, болашақ мамандар, жұлма жад, пәлсапалық жад, адамның жан дүниесі, құзыреттілік, өсетін қабілет, ақыл ой.

\section{А.Ж. Анесова, Е. Жуматаева \\ Роль основных принципов Ж. Аймаутова в преподавании психологии будущим специалистам}

В статье рассмотрены основные принципы Ж. Аймауытова при преподавании психологии для будущих специалистов. Большая роль в этом процессе принадлежит будущим специалистам, которые будут реализовать эти задачи на практике. Подготовка будущих специалистов в высших учебных заведениях и необходимость определения теоретических основ обучения психолого-педагогического наследия Ж. Аймауытова также ставят перед нами задачи. Ж. Аймаутов изучает психологию как источник жизни от экстремальных ситуаций жизни. Он считает, что человеческая душа развивается на основе парных понятий, таких как «дискретная память» и «философская память». При проектировании определенного результата в обучении специалист прогнозирует неизвестное (стохастическое значение) внутреннего мира каждого студента. Здесь эффект не поддается проектированию, а интеллект и свобода - сердце образования. Успешность будущего специалиста заключается в умении анализировать опыт, находить и реализовывать на практике лучшие достижения в обучении. Ж. Аймауытов оставил нам бесценное духовное наследие, приспособив его к национальному образованию. Некоторые советы его, которые исключительно важны в подготовке кадров, направлены на обеспечение индивидуального обучения - основной задачи образования. 
Ключевые слова: базовые национальные идеи, психология, будущие специалисты, дискретная память, философская память, душа человека, компетентность, развивающаяся способность, интеллект.

\section{References}

1 Aimauytov, Zh. (1995). Psikholohiia [Psychology]. Almaty: Rauan [in Kazakh].

2 Aristotel (1983). Shyharmalar zhinahy [Collection of works]. Moskow: Mysl [in Russian].

3 Shormanov, Zh.R.(2004). Zhana tekhnolohiia - zaman talaby [New technology is a requirement of the time]. Almaty: Bilim [in Kazakh].

4 Kunanbayev, A. (2003). Olender zhinahy [Collection of poems]. Pavlodar: HOF «EKO» [in Kazakh].

5 Turisbek, R. (2003). Zhysipbek Aimauytulynyn asemdik alemi [The beauty world of Zhusupbek Aimautov]. Almaty: Kazak universiteti [in Kazakh].

6 Zhumabayev, M. (1999). Pedahohika [Pedagogy]. Almaty: Bilim [in Kazakh].

7 Mazilov, V. (2013). Aktualnye metodolohicheskie problemy sovremennoi psikholohii [Actual methodological problems of modern psychology]. Iaroslavskii pedahohicheskii vestnik (psikholoho-pedahohicheskie nauki) — Yaroslavl Pedagogical Bulletin, psychological and pedagogical sciences, Vol. 2, No. 2, 149-155 [in Russian].

8 Zhumataeva, E. Zhohary mektep didaktikasy [Didactics of high school]. Pavlodar: HOF «EKO» [in Kazakh].

9 Kudarova, N., Tulekova, G., Aubakirova, S., \& Anesova, A. (2019). The role of character in the development of leadership skills of students. Opsion, No. 88, 622-643.

10 Berezov, N., Chepikov, V.T., \& Chekhovsky, M.I. (2004). Fundamentals of psychology and pedagogy. Minsk: New Knowledge LLC [in Russian].

11 Attewell, P., Heil, S., \& Reisel, L. (2011). Competing explanations of undergraduate noncompletion. American Educational Research Journal, No. 48, 536-559.

12 Rybalko, O. (2019). Studying numbering of numbers in elementary school with the use of interactive electronic posters. Bulletin of the Karaganda University. "Pedagogy» series, No. 4 (96), 113. 